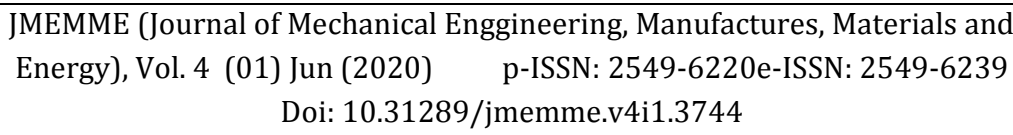

JMEMME (Journal of Mechanical Engineering, Manufactures, Materials and Energy)

\title{
Pemanfaatan Mesin Penghancur Sampah Organik Untuk Memproduksi Pakan Bagi Maggot
}

\section{Utilization Of Organic Waste Destruction Machine To Produce Feed For Maggots}

\author{
Awang Surya* \\ Program Studi Teknik Mesin, Sekolah Tinggi Teknologi Muhammadiyah Cileungsi \\ Diterima: 06-05-2020 ; Disetujui: ; Diterbitkan: 30-06-2020 \\ *Corresponding author: awang_surya@yahoo.com
}

\begin{abstract}
Abstrak
Salah satu kendala yang dihadapi para peternak lele adalah mahalnya harga pakan ikan buatan industri. Salah satu alternatif yang dapat dipergunakan sebagai sumber protein pakan ikan lele adalah Maggot. Tujuan penelitian ini adalah untuk mengetahui sejauh mana efektifitas penggunaan Alat Penghancur Sampah Organik Skala Rumah Tangga di dalam produksi pakan atau umpan bagi maggot. Metode dalam penelitian ini berdasarkan eksperimen dengan menggunakan alat pencacah sampah. Adapun hasil penelitin menggunakan alat konvensional (dengan menggunakan bahan baku dicacah dan bahan baku di cacah menggunakan alat bantu pencacah sampah organik. Dari hasil penelitian tersebut pertumbuhan maggot lebih cepat dibanding maggot yang disuplai makanan dari hasil produksi manual. Berat akhir maggot yang disuplai pakan hasil produksi dengan bantuan alat alat adalah 1361.67 gram, sedangkan maggot yang disuplai makanan hasil produksi manual adalah 1041.67 gram. Selanjutnya perlu diadakan penelitian hubungan penggunaan alat pada pertumbuhan ikan lele.
\end{abstract}

Kata Kunci: Maggot, Ikan Lele, Sampah Organik

\begin{abstract}
One obstacle faced by catfish breeders is the high price of industrial-made fish feed. One alternative that can be used as a protein source for catfish feed is Maggot. The purpose of this study is to determine the effectiveness of the use of Household Scale Organic Waste Crusher in the production of feed or bait for maggot. The method in this study is based on experiments using a garbage chopper. The results of research using conventional tools (using chopped raw materials and chopped raw materials using organic waste counters. From the results of the study maggot growth is faster than maggot supplied by food from manual production. Final weight of maggot supplied by production feeds with the help of tools, it is 1361.67 grams, while maggot supplied with food produced by manual production is 1041.67 grams.
\end{abstract}

Keywords: Maggot, Catfish, Organic Trash 
JMEMME (Journal of Mechanical Enggineering, Manufactures, Materials and Energy), 4 (o1) (2020): 31-39

How to Cite: Surya, A., 2020, Pemanfaatan Mesin Penghancur Sampah Organik Untuk Memproduksi Pakan Bagi Maggot, JMEMME (Journal of Mechanical Enggineering, Manufactures, Materials and Energy), 4(01): 31-39 


\section{PENDAHULUAN}

Kebutuhan protein hewani semakin meningkat seiring dengan pertambahan jumlah penduduk, serta tumbuhnya pemahaman masyarakat akan makanan sehat. [1] Maka kebutuhan akan ikan lele akan semakin meningkat di masa yang akan datang. Sayangnya beternak ikan lele tidak semudah membalik telapak tangan. Selain secara teknis resiko kematian yang cukup tinggi, salah satu kendala yang dihadapi para peternak lele adalah mahalnya harga pakan ikan buatan industri. Hal ini disebabkan tepung ikan sebagai bahan pembuatan pakan sampai saat ini harus diimpor.

Meningkatkan budidaya ikan membutuhkan proses, terutama dalam pemberian pakan, dari nutrisi, tidak harus pakan yang mahal, namun juga pakan ikan yang organik dan bisa dari lingkungan sekitar kita. Pakan yang mempunyai kualitas tinggi, memberikan gizi yang lebih baik untuk pertembuhan ikan. Pakan ikan ini harus berkesinambungan dan tidak ada pengaruhnya terhadap harga maupun kendala terhadap kelangkaan pakan ikan. Budidaya pakan ikan ini tidak hanya bahan mentah di olah menjadi bahan jadi, melainkan memanfaatkan sampah organik untuk menjadi media budidaya lalat hitam, agar dalam proses ternak ikan bisa penurunan biaya pembelian pakan ikan bisa lebih dari 50\%.[2]

Pilihannya adalah menggunakan pakan yang bahan utamanya mudah didapat dan harga yang lebih murah. Bahan baku ini banyak sekali di sekitar kita atau dipasar, dan juga bisa mempergunakan sampah organik [3].
Jika hal itu bisa direalisasikan untuk pakan ikan lele, maka adalah banyak masalah yang bisa diselesaikan. Dampak buruk dari sampah terselesaikan, sekaligus peternak lele akan dapat menekan biaya produksi ikan lele.

Salah satu alternatif yang dapat dipergunakan sebagai sumber protein hewani pakan ikan lele adalah Maggot atau larva dari jenis Black Soldier Fly atau BSF [3]. Kandungan gizi maggot tak kalah dengan pakan ternak yang lain. Kombinasi tepung belatung terbaik dalam pakan ikan cenderung mempengaruhi pertumbuhan ikan lele Sangkuriang. Kombinasi tepung belatung, dalam perlakuan P3 (belatung $30 \%$ dan tepung ikan 70\%) menghasilkan bobot absolut, panjang absolut, berat relatif, panjang relatif, dan efisiensi pakan lebih tinggi daripada perlakuan lain[4] [5].

Maggot yang berasal dari organisme dari telur lalat black soldier [6] fly (BSF) [7] dan pembusuk karena bahan-bahan organik untuk tumbuhtumbuhan, sayur, buah. Adapun proses dalam 1 siklus lalat black soldier maggot (larva), mulai dari prepupa, kemudian pupa, dan menjadi serangga dewasa.[1]

Maggot memiliki kandungan protein kasar cukup tinggi berkisar antara 30-45\%, mengandung asam lemak esensial (linoleat dan linolenat) dan 10 macam asam amino esensial. Maggot black soldier mempunyai ciri khasnya asupan makannya dari sayuran, buah, dan lain. Kebesihan dan nutrisi yang dimakan oleh maggotini lebih bersih dibandingkan dengan lalat rumahan. [8] fly adalah sari bunga. Maggot ini lebih tahan terhadap 
penyakit, dan memiliki kandungan mikroba dan tahan jamur, serta tidak membawa penyakit.

Pemanfaatan BSF sebagai campuran pakan babi [9]. Kalsium yang dibutuhkan untuk pertumbuhan babi [10], meskipun kandungan abunya relatif tinggi [11] [7] [12]

Maggot dapat digunakan sebagai bahan substitusi tepung ikan dan dapat diberikan dalam bentuk segar pada ikan. Larva dari black soldier fly ini juga dapat digunakan sebagai bahan penyusun ransum pakan ikan [13]. Hasil analisa proksimat Laboratorium Teknologi Hasil Perikanan, FPIK-Undip, (2011) maggot mengandung protein $43.42 \%$, lemak $17.24 \%$, serat kasar $18.82 \%$, abu $8.70 \%$ dan kadar air $10.79 \%$ [14].

Pengembangbiakan maggot dapat memanfaatkan sampah organik. Di lain sisi, peneliti sudah pernah merancang bangun alat penghancur sampah organik skala rumah tangga. Alat ini punya kemampuan menghancurkan sampah organik dengan kapasitas 10 Kg/jam.[15] Maka menjadi menarik untuk diadakan penelitian apakah alat penghancur sampah organik yang sudah dibuat bisa dimanfaatkan untuk membantu proses produksi umpan yang bermanfaat bagi pertumbuhan maggot.

Dari latar belakang di atas maka penelitian yang akan dilakukan ini mempunyai tujuan untuk mengetahui manfaat dari hasil Alat Penghancur Sampah Organik Skala Rumah Tangga untuk produksi pakan dari sampah organik bagi maggot.

\section{METODE}

Penelitian ini merupakan jenis penelitian eksperimen dan untuk mengetahui pengaruh penggunaan "Alat Penghancur Sampah Organik Skala Rumah Tangga" (APSOSRT) sebagai sarana produksi umpan bagi maggot.

Penelitian ini menggunakan rancangan sebagai berikut :

- Proses produksi maggot dibagi menjadi dua kelompok cara produksi

- Kelompok 1: Produksi maggot di mana pakan/umpan yang dibuat dari sampah organik dihancurkan dengan tangan dengan menggunakan alat bantu yang selama ini digunakan di tempat peternakan lele milik Pak Ari Susanto yang berada di Kampung Cikukulu, Desa Cipenjo, Kecamatan Cileungsi, Kabupaten Bogor. Alat yang biasa digunakan adalah pisau. Kelompok ini disebut kelompok produksi MANUAL

- Kelompok 2: Produksi maggot di mana pakan/umpan yang dibuat dari sampah organik dikerjakan dengan menggunakan APSOSRT (Alat Penghancur Sampah Organik Skala Rumah Tangga). Kelompok ini disebut dengan kelompok produksi DENGAN ALAT

- Masing-masing jenis cara produksi ada 3 baskom (baki tempat pertumbuhan maggot)

- Bibit awal adalah larva maggot yang berusia 1 minggu

- Jumlah awal bibit pada masingmasing baskom sama yaitu 100 gram

- Perkembangan pertumbuhan maggot pada masing-masing baskom 
Surya, A., Pemanfaatan Mesin Penghancur Sampah Organik ...

diamati setiap hari dan dicatat setiap minggu.

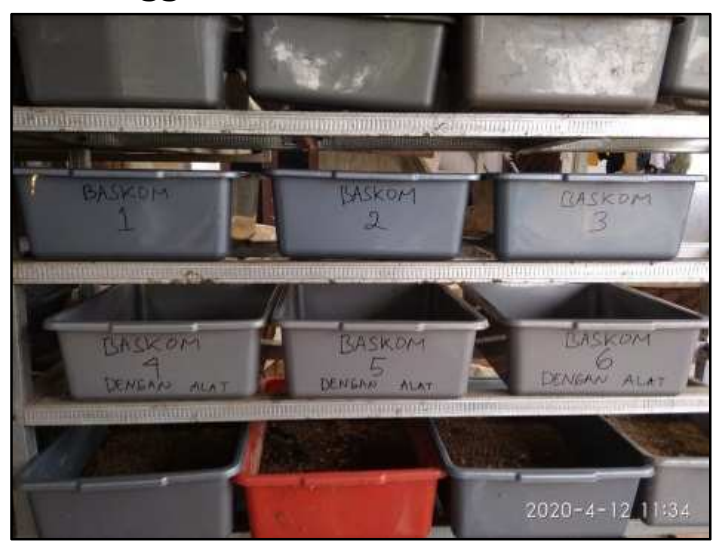

Gambar 1. Tempat pengembangan maggot

\subsection{Waktu dan Tempat}

Penelitian ini dilaksanakan di peternakan lele milik Pak Ari Susanto, di Kampung Cikukulu, Desa Cipenjo, Kecamatan Cileungsi, Kabupaten Bogor. Penelitian dilakukan antara tanggal 12 April 2020 sampai 3 Mei 2020

\subsection{Alat dan bahan.}

Pada penjelasan tabel 1 alat dan bahan yang dipergunakan dalam penelitian.

Tabel 1. Daftar alat penelitian

\begin{tabular}{|l|l|l|}
\hline NO & NAMA ALAT & \multicolumn{1}{|c|}{ KEGUNAAN } \\
\hline 1 & APSOSRT & $\begin{array}{l}\text { Menghancurkan } \\
\text { sampah organik yang } \\
\text { akan dijadikan } \\
\text { pakan/umpan maggot }\end{array}$ \\
\hline 2 & Pisau & $\begin{array}{l}\text { Membantu } \\
\text { menghancurkan } \\
\text { sampah organik } \\
\text { dengan tangan }\end{array}$ \\
\hline 3 & Baskom & $\begin{array}{l}\text { Tempat pengembang } \\
\text { biakan bibit maggot }\end{array}$ \\
\hline 4 & Ember & $\begin{array}{l}\text { Menampung sampah } \\
\text { organik }\end{array}$ \\
\hline 5 & $\begin{array}{l}\text { Timbangan } \\
\text { digital }\end{array}$ & $\begin{array}{l}\text { Menimbang berat } \\
\text { maggot }\end{array}$ \\
\hline 6 & Alat tulis & $\begin{array}{l}\text { Mencatat } \\
\text { perkembangan maggot }\end{array}$ \\
\hline 7 & Gergaji & $\begin{array}{l}\text { Memotong material } \\
\text { rak tempat baskom } \\
\text { (baki) }\end{array}$ \\
\hline
\end{tabular}

\begin{tabular}{|l|l|lr|}
\hline 8 & Bor & $\begin{array}{l}\text { Alat bantu membuat } \\
\text { rak }\end{array}$ \\
\hline 7 & Handphone & $\begin{array}{l}\text { Mengambil gambar } \\
\text { (foto) }\end{array}$ \\
\hline
\end{tabular}

Bahan utama yang digunakan adalah:

1. sampah organic

2. bibit maggot yang sudah berumur 7 hari.

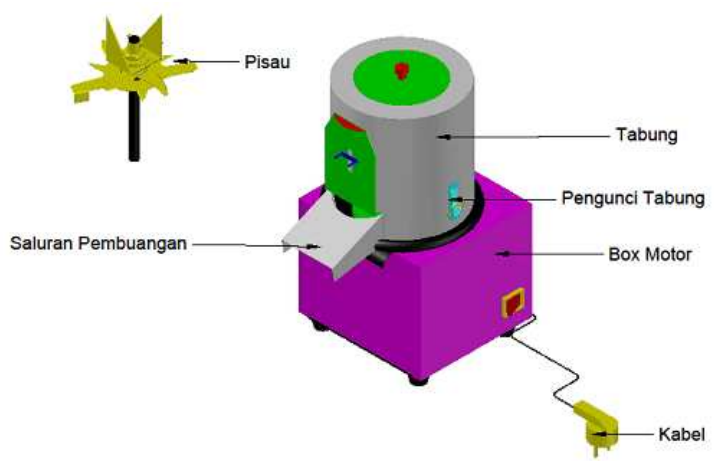

Gambar 2. Alat penghancur sampah organik skala rumah tangga [15]

\subsection{Variabel Pengamatan}

Variable utama yang diamati adalah pertumbuhan maggot yang ada di setiap baskom. Dalam hal ini pertumbuhan diamati dengan mengukur berat maggot pada masing-masing baskom. Pengamatan dilakukan setiap 7 hari sekali.

\section{HASIL DAN PEMBAHASAN}

Dari penelitian yang telah dilakukan maka didapat data perkembangan maggot pada setiap baskom sebagai berikut: 
Tabel 2. Perkembangan berat maggot manual

\begin{tabular}{|c|c|c|c|}
\hline $\begin{array}{c}\text { NO. } \\
\text { BASKOM }\end{array}$ & $\begin{array}{c}\text { BERAT } \\
\text { HARI 7 } \\
\text { gram }\end{array}$ & $\begin{array}{c}\text { BERAT } \\
\text { HARI 14 } \\
\text { gram }\end{array}$ & $\begin{array}{c}\text { BERAT } \\
\text { HARI 21 } \\
\text { gram }\end{array}$ \\
\hline 1 & 315.00 & 760.00 & 1050.00 \\
\hline 2 & 295.00 & 760.00 & 1135.00 \\
\hline 3 & 280.00 & 820.00 & 940.00 \\
\hline Rata-rata & 296.67 & 780.00 & 1040.67 \\
\hline
\end{tabular}

Tabel 3. Perkembangan berat maggot dengan

\begin{tabular}{|c|c|c|c|}
\hline \multicolumn{5}{|c}{ NO. } & BERAT & BERAT & BERAT \\
BASKOM & HARI 7 & HARI 14 & HARI 21 \\
& gram & gram & gram \\
\hline 4 & 370.00 & 1135.00 & 1145.00 \\
\hline 5 & 390.00 & 1080.00 & 1410.00 \\
\hline 6 & 395.00 & 1015.00 & 1230.00 \\
\hline Rata-rata & 385.00 & 1076.67 & 1361.67 \\
\hline
\end{tabular}

Dari data tersebut dapat dibuat grafik perbandingan pertumbuhan maggot seperti gambar 3 .

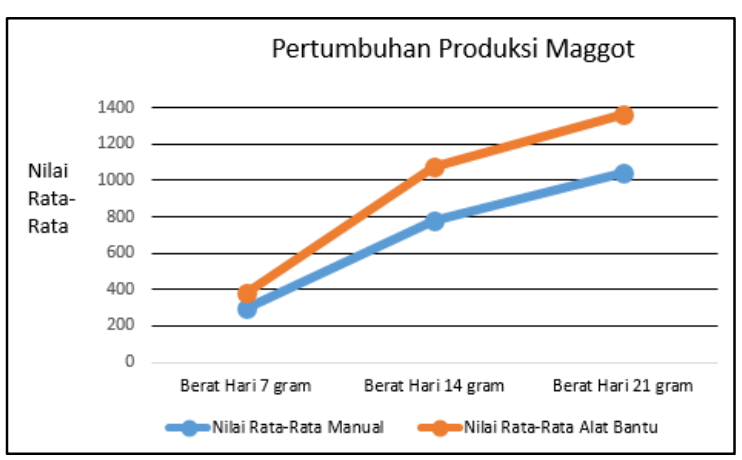

Gambar 3. Grafik Pertumbuhan Maggot

Dari grafik di atas terlihat jelas bahwa pertumbuhan maggot pada metode produksi dengan alat jauh lebih tinggi dibandingkan produksi secara manual. Pada minggu pertama perbedaan pertumbuhan sudah terlihat. Pada minggu pertama berat rata-rata maggot pada produksi manual adalah
296.67 Gram dan pada produksi dengan alat sebesar 385.00 gram.

Selama penelitian dilaksanakan terlihat di baskom produksi dengan alat makanan lebih cepat habis. Pada minggu pertama terlihat bahwa di dalam 24 jam kelompok produksi dengan alat harus disuplai makanan tiga kali. Sementara pada kelompok produksi manual hanya dua kali dengan keadaan makanan masih terlihat sisa.

Pada minggu kedua berat rata-rata maggot pada produksi manual adalah 780.00 gram dan pada produksi dengan alat sebesar 1076.67 gram. Ada selisih 296,67 gram. Selain itu pada minggu kedua sudah terlihat jelas perbedaan ukuran maggot pada masing-masing metode. Pada metode produksi dengan alat maggot jauh lebih panjang dan besar. Panjang rata-rata maggot pada metode ini adalah $15 \mathrm{~mm}$. Pada keadaan ini sebenarnya maggot sudah bisa dipergunakan untuk umpan jika keadaan memaksa misalnya pakan lain tidak ada. Sementara untuk metode produksi manual ukuran maggot masih terlalu kecil sehingga belum bisa dipergunakan sebagai pakan. Panjang rata-rata maggot produksi metode manual pada minggu kedua adalah $9 \mathrm{~mm}$.

Pada minggu kedua pertumbuhan maggot semakin cepat. Bisa dilihat dari gambar 3. Dari penelitian juga ditemukan fakta bahwa kebutuhan makan di masing-masing kelompok produksi juga meningkat. Kebutuhan suplai makanan maggot meningkat antara tiga sampai empat kali lipat.

Pada minggu ketiga berat rata-rata maggot pada produksi manual adalah 1040.67 gram dan pada produksi dengan 
alat sebesar 1361.67 gram. Selain itu panjang rata maggot juga terdapat selisih. Pada produksi manual panjang rata-rata maggot pada minggu ketiga adalah $12 \mathrm{~mm}$, sedangkan pada produksi dengan alat sepanjang $19 \mathrm{~mm}$.

Pertumbuhan maggot pada metode dengan bantuan alat terlihat lebih tinggi disebabkan makanan atau umpan yang diproduksi dengan alat lebih lembut atau ukuran butirannya lebih kecil. Ukuran butiran atau potongan bahan makan ini berpengaruh pada kecepatan maggot menyantap makanan.

Selain dari pertumbuhan berat maggot, dari pengamatan selama penelitian terlihat bahwa kondisi baskom tempat maggot yang disuplai makananan menggunakan alat terlihat lebih bersih dan tidak menyisakan sampah lagi. Sementara pada baskom yang disuplai makanan hasil produksi secara manual terlihat kotor dan masih banyak sampah tersisa.

Perbandingan penampakan fisual dari kedua macam metoda terlihat seperti pada gambar 4 dan 5 .

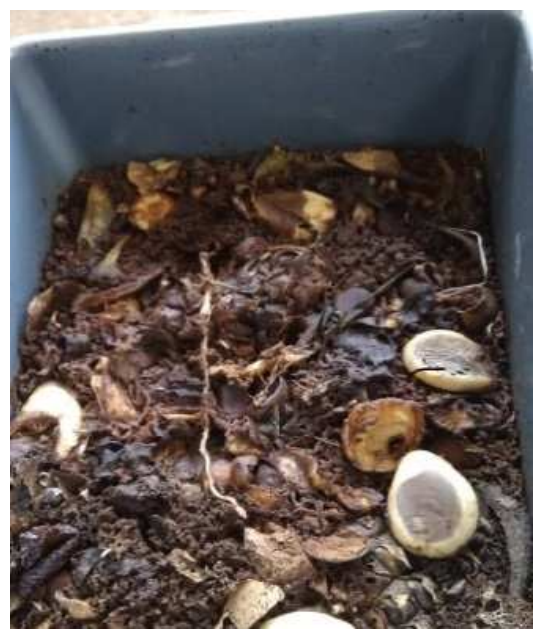

Gambar 4. Keadaan Baskom Produksi Manual

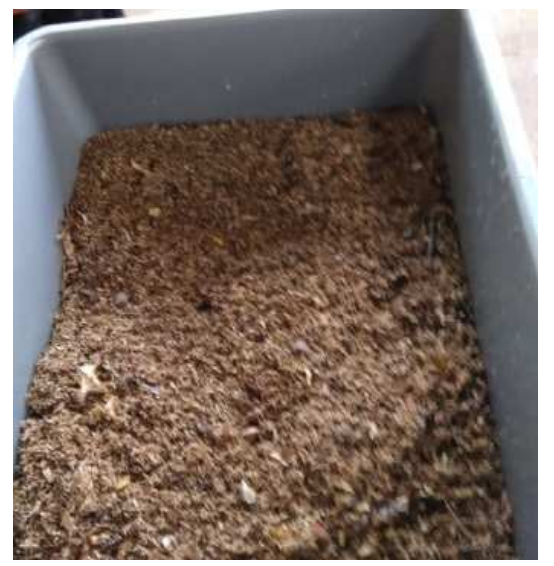

Gambar 5. Keadaan Baskom Produksi Menggunakan Alat

Dari data pengamatan fisual tersebut semakin memperkuat bahwa makanan yang diproduksi dengan menggunakan alat bantu Alat Penghancur Sampah Organik Skala Rumah Tangga (APSOSRT) lebih disukai oleh maggot. Terbukti semua makanan dilahap sampai tidak tersisa. Sementara makanan yang diproduksi secara manual kurang disukai terbukti masih banyak tersisa.

Makanan yang tersisa terlihat masih dalam bentuk ukuran potongan yang besar. Artinya, hasil produksi umpan secara manual menghasilnya makanan yang tidak bagus. Besarnya potongan sangat bervariasi. Ini sangat mungkin dipengaruhi oleh kondisi pekerja yang memotong sampah organik. Lain orang akan lain pula hasil kerjanya. Juga hasil kerja di awal akan sangat berbeda dengan hasil kerja dalam keadaan pekerja sudah lelah karena bekerja beberapa jam.

Dalam hal kecepatan produksi juga terdapat perbedaan yang signifikan. Alat Penghancur Sampah Organik Skala Rumah Tangga yang dipergunakan dalam penelitian ini punya kapasitas 
produksi $10 \mathrm{Kg} /$ jam[15]. Sementara itu untuk menghancurkan sampah organik secara manual, yaitu dengan menggunakan pisau diperlukan waktu rata-rata 30 menit untuk sampah sebanyak $1 \mathrm{Kg}$. Jadi kapasitas produksi makanan maggot dari sampah organik yang dilakukan secara manual adalah:

$$
\begin{aligned}
\mathrm{C} & =(1 / 30) \times 60 \\
& =2 \mathrm{Kg} / \mathrm{jam}
\end{aligned}
$$

Jadi dengan menggunakan alat bantu Alat Penghancur Sampah Organik Skala Rumah Tangga kapasitas produksi makanan maggot menjadi lebih tinggi, yaitu 5 kali lebih cepat. Sehingga waktu yang dipergunakan untuk memproduksi pakan bisa digunakan untuk mengerjakan pekerjaan lain.

\section{KESIMPULAN}

Produksi pakan maggot dengan alat bantu Alat Penghancur Sampah Organik Skala Rumah Tangga lebih baik daripada produksi pakan secara manual. Berat akhir maggot yang disuplai pakan hasil produksi dengan bantuan alat alat adalah 1361.67 gram sedangkan maggot yang disuplai makanan hasil produksi manual adalah 1041.67 gram. Kapasitas produksi pakan dengan alat lima kali lebih besar dibanding produksi pakan secara manual. Sehingga waktu yang dipergunakan untuk membuat pakan dengan bantuan alat lebih sedikit, sisa waktu bisa dimanfaatkan untuk pekerjaan lain. Pada proses produksi pakan secara manual ditemukan banyak sampah organik yang tidak habis dimakan oleh maggot sehingga terbuang percuma. Ukuran maggot yang disuplai pakan dengan bantuan alat lebih panjang dan besar disbanding maggot yang pakannya diproduksi secara manual. Jika dikehendaki pada minggu kedua maggot yang diberi umpan produksi dengan bantuan alat sudah bisa dipanen, sementara pada metode manual belum bisa. Selanjutnya perlu diadakan penelitian lanjutan untuk mengetahui pengaruh penggunaan alat penghancur sampah organik skala rumah tangga pada pertumbuhan ikan lele, karena produk akhir dari peternakan lele adalah ikan lele.

\section{PENGHARGAAN}

Kami ucapakan terima kasih kepada STTMC yang telah memberikan dana penelitian, sehingga terselasaikan penelitian dosen pemula dan kami ucapkan terima kasih kepada LPPM yang mensupport dalam hal penelitian dosen.

\section{REFERENCES}

[1] R. Ula, A. Fauzi, E. Resty, and N. Sari, "Analisis Usaha Budidaya Maggot sebagai Alternatif Pakan Lele Business Analysis of Maggot Cultivation as a Catfish Feed Alternative," J. Teknol. dan Manaj. Agroindustri, 2018, doi: 10.21776/ub.industria.2018.007.01 .5 .

[2] M. S. I. Abdul Manan, "Aplikasi Larva Black Soldier Fly (Hermatia illucens) Sebagai Pakan Alami Dan Pakan Buatan (Pelet) Untuk Ikan Rainbow Kurumoi (Melanotaenia parva) $<$ br $><$ i $>$ [Application Of Black Soldier Fly Larval (Hermetia illucens) As Feed And Artificial Feed (Pellets) For," J. Ilm. Perikan. dan Kelaut., 2019, doi: 10.20473/jipk.v5i2.11397.

[3] F. K. Attiogbe, N. Y. K. Ayim, and J. Martey, "Effectiveness of black soldier fly 
Surya, A., Pemanfaatan Mesin Penghancur Sampah Organik ...

larvae in composting mercury contaminated organic waste," Sci. African, vol. 6, 2019, doi: 10.1016/j.sciaf.2019.e00205.

[4] Meitiyani, E. Ratika, A. P. Dharma, and R. Annisa, "Combination of Hermetia illucens L Maggot Flour with Fish Feed against Growth of Sangkuriang Catfish (Clarias sp)," Syst. Rev. Pharm., vol. 11, no. 1, pp. 529-535, 2020, doi: 10.5530/srp.2020.1.66.

[5] "EFEKTIVITAS SUBSTITUSI TEPUNG IKAN DENGAN TEPUNG MAGGOT DALAM PAKAN BUATAN TERHADAP PERTUMBUHAN DAN KELULUSHIDUPAN IKAN PATIN (The Effect of Substitution of Fish Meal with Maggot Meal in Artificial Feed for Growth And Survival Rate of Catfish)," 2013, doi: 10.14710/ijfst.9.1.62-67.

[6] B. Dortmans, S. Diener, B. Verstappen, and C. Zurbrügg, Black Soldier Fly Biowaste Processing. 2017.

[7] A. H. Wardhana, "Black soldier fly (Hermetia illucens) sebagai sumber protein alternatif untuk pakan ternak," War. Bul. Ilmu Peternak. dan Kesehat. Hewan Indones., 2016, doi:

10.14334/wartazoa.v26i2.1327.

[8] Matsumoto, “No 主観的健康感を中心と した在宅高齢者における 健康関連 指標に関する共分散構造分析

Title," 2018.

[9] R. D. Larry Newton, Craig Sheppard, Wes D, Watson, Gary Burtle, "USING THE BLACK SOLDIER FLY, Hermetia illucens, AS A VALUE-ADDED TOOL FOR THE MANAGEMENT OF SWINE MANURE," J. Korean Entomol. Appl. Sci., vol. 36, no. 12, p. 17 pp., 2005.

[10] I. Biasato et al., "Partially defatted black soldier fly larva meal inclusion in piglet diets: Effects on the growth performance, nutrient digestibility, blood profile, gut morphology and histological features," J. Anim. Sci. Biotechnol., vol. 10, no. 1, pp. 1-11, 2019, doi: 10.1186/s40104-0190325-x.

[11] N. Meijer, G. Bosch, M. Veenenbos, J. J. van Loon, H. van Zanten, and I. van der Fels-Klerx, "The residual biomass landscape for insect production," Bornimer Agrartech. Berichte, no. September, p. 54, 2017.

[12]E. I. Raharjo, . R., and A. Muhamad, "PENGARUH KOMBINASI MEDIA AMPAS KELAPA SAWIT DAN DEDAK PADI TERHADAP PRODUKSI MAGGOT (Hermetia illucens)," J. Ruaya J. Penelit. dan Kaji. Ilmu Perikan. dan Kelaut., 2016, doi: 10.29406/rya.v4i2.702.

[13] I. Swinscoe et al., "Seaweed-fed black soldier fly (Hermetia illucens) larvae as feed for salmon aquaculture: Assessing the risks of pathogen transfer," J. Insects as Food Feed, vol. 5, no. 1, pp. 15-27, 2019, doi: 10.3920/JIFF2017.0067.

[14] D. Rachmawati, "EFEKTIVITAS SUBSTITUSI TEPUNG IKAN DENGAN TEPUNG MAGGOT DALAM PAKAN BUATAN TERHADAP PERTUMBUHAN DAN KELULUSHIDUPAN IKAN PATIN (The Effect of Substitution of Fish Meal with Maggot Meal in Artificial Feed for Growth And Survival Rate of Catfish)," vol. 9, no. 1, pp. 62-67, 2013, doi: 10.14710/ijfst.9.1.62-67.

[15] A. S. Surya, F. Azharul, and W. Arso, "RANCANG BANGUN ALAT PENGHANCUR SAMPAH ORGANIK SKALA RUMAH TANGGA," J. Mech. Eng. Manuf. Mater. ENERGY, 2019, doi: 10.31289/jmemme.v3i2.2893. 